J. Amer. Soc. Hort. Sci. 115(2):207-212. 1990.

\title{
Planting Method and Irrigation Rate Influence Vegetative and Reproductive Growth of Peach Planted at High Density
}

\author{
J.G. Williamson ${ }^{1}$ and D.C. Coston ${ }^{2}$ \\ Department of Horticulture, Clemson University, Clemson, SC 29634-0375 \\ Additional index words. Prunus persica, root restriction, trickle irrigation, regulated deficit, high-density orchard
}

\begin{abstract}
Several planting treatments modified vegetative and reproductive growth of young, own-rooted peach (Prums persica) trees evaluated at two levels of irrigation in a high-density orchard (5000 trees/ha). Trees planted in auger holes, narrow herbicide strips, and in fabric-lined trenches, but not those from raised beds, were smaller than control trees set in holes dug with a shovel. After two growing seasons, trees planted in the fabric-lined trenches were smaller and had more flowers per node and greater flower bud densities than trees in other planting treatments. Yield efficiency was greatest for this treatment, although fruit size was small throughout the orchard. Irrigation rates did not affect fruit yield or size. The effects of irrigation rate on vegetative growth were small compared to differences among planting treatments.
\end{abstract}

Controlling vigor of fruit trees has been a major goal of pomologists for centuries. Achieving a proper balance between vegetative and reproductive growth is necessary to enhance production early in the orchard's life and to maximize yields during the entire life of the orchard. Commercially acceptable dwarfing rootstock for peach in the southeastern United States have not been identified. Summer pruning and various growth-regulating compounds have offered some suppression of vigor, yet these practices can be costly and often have adverse side effects.

Root restriction of hydroponically grown peach seedlings resulted in less root and shoot growth with a root : shoot ratio similar to non-restricted plants (Richards and Rowe, 1977). Cockroft and Wallbrink (1966) reported that peach tree vigor was related to the volume of soil readily accessible to the root system.

Chalmers et al. (1981) and Mitchell and Chalmers (1983) in Australia reduced vigor of peach without adversely affecting fruit development by applying reduced rates of irrigation during stages 1 and 2 of fruit growth followed by higher irrigation rates during stage 3 of fruit growth. Infrequent precipitation and confinement of the root system by shallow top soil allowed for more precise control of vegetative growth in Australia than could normally be expected from similar practices in the humid southeastern United States.

In humid regions with deep, well-drained soils, the horizontal and vertical spread of the peach root system can be extensive (Havis, 1938; Oskamp, 1933). Cultural methods to restrict roots and manipulation of plant water status in the field could allow

Received for publication 15 Feb. 1989. Technical contribution no. 2934 of the South Carolina Agricultural Experiment Station, Clemson Univ. The cost of publishing this paper was defrayed in part by the payment of page charges. Under postal regulations, this paper therefore must be hereby marked advertisement solely to indicate this fact.

'Former Research Assistant. Present address: Fruit Crops Dept., Univ. of Florida, Gainesville, FL 32611.

${ }^{2}$ Professor, Dept. of Horticulture. for greater control of vegetative growth, especially in humid regions with abundant spring rains and deep, fertile soils. The objective of this study was to evaluate the effects of planting methods under two irrigation regimes for peach tree growth and production.

\section{Materials and Methods}

A high-density peach orchard (5000 trees/ha) was established during Summer 1984. The site consisted of well-drained, moderately permeable Cecil and Appling soils. Each is classified as clayey, Kaolinite, Thermic Type Hapludults. Before planting, the orchard floor was limed, subsoiled, disked, rototilled, and fumigated with methyl bromide. Own-rooted 'Redhaven' peach trees, propagated from hardwood cuttings the previous winter, were used. Trees were trained to central leaders and planted at an in-row spacing of $1 \mathrm{~m}$, with $2 \mathrm{~m}$ between rows. Each plot contained 15 trees (three rows of five trees). The three middle trees in the middle row of each plot were used for data collection.

The experimental design was a randomized complete block with four to seven replications, depending on the characteristic measured. Each 15-tree plot was duplicated at the beginning of the study so that two irrigation treatments could be imposed on each planting treatment during 1986 . The result was a $5 \times 2$ factorial assignment of treatments with individual 15 -tree plots for each planting treatment/irrigation level combination. Data were analyzed using analysis of variance and means were separated by LSD (5\% level).

Five planting treatments were used: 1) control-trees set in holes dug with a shovel just large enough to accommodate the root system; 2) auger planting hole-trees set in 45-cm-deep holes dug with a $20-\mathrm{cm}$ auger under wet soil conditions, which resulted in compaction of the clay subsoil at the sides of the hole; 3) raised bed-top soil pulled from between rows into rows to form beds $\approx 1.0 \mathrm{~m}$ wide $\times 20 \mathrm{~cm}$ high with trees centered on top of the bed; 4) narrow herbicide strip (NHS) - 
trees planted as controls within 0.5-m-wide herbicide strips (herbicide strips for all other treatments were maintained at a width of $1.0 \mathrm{~m})$; 5) fabric-lined trench (FLT) - trees planted in Vshaped trenches $90 \mathrm{~cm}$ wide $\times 30 \mathrm{~cm}$ deep that were lined with a synthetic polyester fabric impregnated with an acrylic latex (Trevira Spunbond No. 533251, American Hoechst Corp., Atlanta, Ga.). Weed-free herbicide strips were maintained with repeat applications of paraquat.

'Kentucky 31' tall fescue (Festuca arundinacea Schreb.) was established as a permanent sod between the tree rows. Adequate levels of essential mineral elements other than $\mathrm{N}$ were established before planting, based on soil test recommendations for peach. During 1984, one application of $\mathrm{N}$ as $\mathrm{CaNO}_{3}$ was broadcast in a 2-m-wide band in the row at a rate of $7 \mathrm{~g}$ of $\mathrm{N} /$ linear meter of row. During 1985 and 1986, three applications (April, June, and August) of $\mathrm{N}$ were made as either $\mathrm{CaNO}_{3}$ or $\mathrm{NH}_{4} \mathrm{NO}_{3}$ at a rate of $22 \mathrm{~g} \mathrm{~N} /$ linear meter of row per year and $30 \mathrm{~g} \mathrm{~N} /$ linear meter of row per year, respectively.

Overhead and drip irrigation were used during the remainder of the 1984 growing season to minimize transplanting shock. During the 1985 growing season, all treatments received $\approx 35$ liters of water/week per tree via drip irrigation, consisting of one emitter/tree located 20 to $30 \mathrm{~cm}$ from the trunk. In Spring 1986, two irrigation levels were imposed. One-half of the duplicated plots of each planting treatment received a high irrigation level that replaced $100 \%$ of the estimated daily evapotranspiration (ET) during all stages of fruit development, based on class A evaporation pan readings, with an estimation of canopy area and a crop coefficient of 0.7 . The other half received a low irrigation level that replaced $12.5 \%$ of the estimated ET during stages 1 and 2 of fruit growth and $100 \%$ of estimated ET during stage 3. Irrigations were usually made at 1- to 2-day intervals, depending on weather conditions.

Trunk diameter (measured $5 \mathrm{~cm}$ above the soil surface), tree height, and number of first-order lateral shoots (originating from the central leader) per plant were measured at the end of the 1984 growing season. Trunk diameter, tree height, and canopy width were measured at the end of the 1985 and 1986 growing seasons. The number of flower buds was determined in Spring 1986 from four representative shoots on each of three trees per treatment in each replication. Lateral shoot diameter (measured $1.5 \mathrm{~cm}$ from the basal portion of the 1-year-old wood), shoot length, number of nodes, number of second-order lateral shoots, and number of flowers/node on first and second lateral shoots were recorded.

Elongation of first-order lateral shoots was measured at weekly intervals for four shoots from each treatment replicated six times beginning 29 Apr. 1986 and ending 21 June. Similarly, diameters of four fruit from each treatment replicated four times were measured at weekly intervals to determine the onset of stages 2 and 3 of fruit growth (data not reported). At the end of stage 1 of fruit growth, diameters of all fruit on two of the four shoots previously selected for vegetative growth determinations were measured. Hand-thinning 35 days after flowering left about one fruit per $15 \mathrm{~cm}$ of shoot length. Fruit were harvested at commercial maturity based on ground color (Delwiche and Baumgardner, 1983) on 23 June, 26 June, and 3 July. Fruit were sorted, weighed, and counted with a Durand-Wayland microsizer (LaGrange, Ga.). Samples of 15 fruit per plot were proportionally selected from each size category for each harvest date. Individual fruit diameters and weights were determined.

Leaves for foliar analysis and leaf size determinations were sampled from the middle portion of representative shoots from each plot. Samples were taken 24 June in 1985 and 7 June in 1986. Fifty leaves/plot and 20 leaves/plot were used for foliar analysis and leaf size determinations, respectively. Leaves collected for elemental analysis were rinsed in deionized water, dried at 70C, and ground in a Wiley mill (Arthur H. Thomas Co., Philadelphia) equipped with a 20 -mesh screen. Elemental analysis was conducted by the Dept. of Agricultural Chemical Services (Clemson Univ. Clemson, S.C.). Leaf size was determined with a LI-COR LI-3000 area meter (Lincoln, Neb.).

\section{Results}

Planting treatments $\times$ irrigation level interactions were not significant; therefore, only main effects are presented.

Planting method effects. In 1984, trees planted in auger holes grew less than trees in other planting treatments (Table 1). Tree height, trunk diameter, and mean number of lateral shoots per tree were less for auger-planted trees than for control trees. Trees planted in auger holes remained smaller than control trees throughout the 1985 and 1986 growing seasons, except for canopy width in 1986. In 1985, tree height, trunk diameter, and canopy width were less for trees grown in narrow herbicide strips (NHS) and for trees planted in the fabric-lined trenches (FLT) than for control trees. The same was true in 1986, except that canopy width of NHS trees did not differ from that of control trees. After three growing seasons, FLT trees were smaller than trees in any of the other treatments for all growth characteristics measured. Preliminary excavations during Winter 198687 indicated that few roots from these trees were outside the zone defined by the fabric. The growth habits of the FLT trees and control trees are illustrated in Fig. 1.

Measurements of weekly shoot growth in 1986 illustrate that the suppression of vegetative growth from the FLT treatment occurred early and persisted throughout the season (Fig. 2). Although differences in shoot length were noted between trees planted in raised beds and the control trees at a few measuring dates (data not shown), large, consistent reductions in shoot length were observed only for the FLT trees (Fig. 2).

Flower bud density was greater for FLT trees than for trees in other treatments (Table 2). The higher flower bud density of FLT trees was primarily the result of an increase in flowers/ node, since their internode length was not affected.

Planting treatment did not affect fruit diameter at the end of stage 1 of fruit growth (Table 3). Although control trees were larger than FLT trees, there was no difference in the number of fruit per tree. The NHS trees had fewer fruit at harvest than those of the other treatments. Fruit yield per tree (weight) did not differ between the control and FLT trees. However, yield efficiency $\left(\mathrm{kg} \cdot \mathrm{m}^{-2}\right.$ of trunk cross-sectional area) was greatest for FLT trees. Fruit diameters of the FLT trees were smaller than fruit from control trees at the first two harvests. However, the magnitude of the differences was not great.

Leaf N concentration for NHS trees was lower than for those of other planting treatments in 1986 (Table 4). Phosphorus concentrations were lower in leaves of FLT trees when compared to controls in 1985 and 1986. Similarly, leaf $\mathrm{Cu}$ concentrations were lower for NHS and FLT trees than for control trees during both years. Other elements analyzed were not affected by planting treatments.

Irrigation effects. In 1986, deficit irrigation during stages 1 and 2 of fruit growth (12.5\% ET replacement) reduced canopy width (Table 1) and leaf size (data not shown), but not tree height or trunk diameter. Irrigation rate had no effect on yield, yield efficiency, mean fruit weight (data not shown), or mean 
Table 1. Effect of planting treatments and irrigation levels on vegetative growth of 'Redhaven' peach trees.

\begin{tabular}{|c|c|c|c|c|c|c|c|c|c|c|}
\hline \multirow{2}{*}{$\begin{array}{l}\text { Planting } \\
\text { treatment }\end{array}$} & \multirow{2}{*}{$\begin{array}{l}\text { Irrigation } \\
\text { level }(\%)^{z}\end{array}$} & \multicolumn{3}{|c|}{ Tree ht $(\mathrm{cm})$} & \multicolumn{3}{|c|}{ Trunk diam $(\mathrm{cm})$} & \multirow{2}{*}{$\begin{array}{c}\begin{array}{c}\text { Lateral } \\
\text { shoots/plant }\end{array} \\
1984\end{array}$} & \multicolumn{2}{|c|}{$\begin{array}{c}\text { Canopy } \\
\text { width }(\mathrm{cm})\end{array}$} \\
\hline & & 1984 & 1985 & 1986 & 1984 & 1985 & 1986 & & 1985 & 1986 \\
\hline Control & & 45.5 & 217 & 286 & 1.0 & 4.0 & 4.7 & 4.6 & 155 & 183 \\
\hline Auger & & 32.4 & 192 & 266 & 0.8 & 3.5 & 4.4 & 1.4 & 144 & 177 \\
\hline Raised bed & & 45.8 & 210 & 280 & 1.1 & 3.7 & 4.6 & 5.3 & 154 & 188 \\
\hline NHS $^{y}$ & & 45.8 & 193 & 258 & 1.1 & 3.2 & 4.1 & 4.3 & 126 & 173 \\
\hline FLT $x$ & & 49.8 & 183 & 211 & 1.1 & 3.1 & 3.5 & 6.0 & 120 & 153 \\
\hline $\operatorname{LSD}(0.05)$ & & 7.1 & 13.0 & 15.8 & 0.1 & 0.3 & 0.3 & 1.9 & 9.9 & 14.7 \\
\hline & 100 & -- & -- & 265 & $\cdots$ & --- & 4.3 & -- & 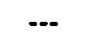 & 180 \\
\hline . & 12.5 & --- & --- & 255 & -- & --- & 4.2 & -- & $\cdots$ & 169 \\
\hline $\begin{array}{l}\text { Significance between } \\
\text { irrigation levels }\end{array}$ & & -- & $-\cdots$ & NS & --- & $\cdots$ & NS & --- & -- & $*$ \\
\hline
\end{tabular}

${ }^{2}$ Evapotranspiration replaced.

y Narrow herbicide strip.

xFabric-lined trench.

Ns, Nonsignificant or significant at $P=0.05$, respectively, Fisher's F-test.

fruit diameter at harvest (Table 3). However, at the end of stage 1 of fruit growth, fruit diameters of trees irrigated at $12.5 \% \mathrm{ET}$ were smaller than fruit diameters for trees receiving $100 \% \mathrm{ET}$. Deficit irrigation resulted in higher leaf $\mathrm{N}$ and $\mathrm{Zn}$ and lower
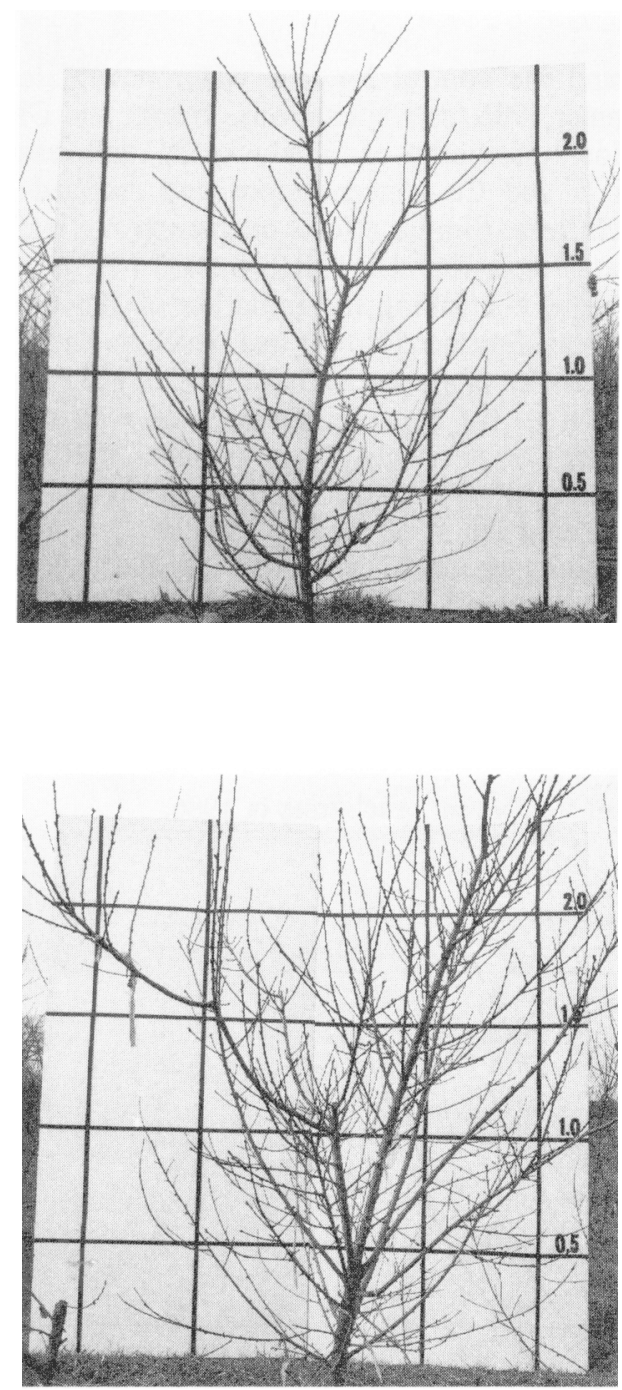

Fig. 1. 'Redhaven' peach trees after three growing seasons (before dormant pruning): (top) grown in trench lined with a polyester fabric; (bottom) grown without root restriction. leaf Ca than $100 \%$ ET replacement (Table 4). Other elements analyzed were not affected by irrigation treatment.

\section{Discussion}

Preliminary excavations indicated that the polyester lining the trenches of the FLT treatment imposed limitations on peach tree root distribution. Limitations on the growth of root systems eventually result in reduced growth of aerial plant parts. Richards and Rowe (1977) demonstrated this concept by restricting the root systems of hydroponically grown peach seedlings. Root restriction resulted in reduced vegetative growth even when water and nutrients were nonlimiting. Removal of portions of the root systems of various plants have caused similar responses (Buttrose and Mullins, 1968; Kende, 1965; Richards and Rowe, 1977). Roots are a source of cytokinins (Kende, 1965; Sitton et al., 1967; Vaadia and Itai, 1968), gibberellins (Phillips and Jones, 1964) ACC (Bradford and Yang, 1980 and 1981), and amino compounds (Waring, 1970), all of which may play a role in coordinating growth between the roots and shoots. It is possible that trees in the FLT treatment were inhibited in the synthesis and/or translocation of one or more of these compounds from the roots. Richards and Rowe (1977) reported that exogenous applications of 6-benzylaminopurine (BA) overcame the effects of root restriction on shoot growth.

Root restriction in the field would be more likely to impose limitations on water and nutrient availability than in the carefully controlled experimental conditions of Richards and Rowe (1977). Regulated deficit irrigation has been used successfully to control vigor in high-density peach orchards in arid regions of Australia (Chalmers et al., 1981; Mitchell and Chalmers, 1983). In those experiments, the natural restriction of the root system to the shallow topsoil coupled with infrequent precipitation during periods of vegetative growth allowed for precise control of plant water status through careful management of irrigation.

The auger hole treatment effect was inconsistent, but did result in reduced growth, although not to the extent of FLT trees. NHS trees were smaller than control trees and larger than FLT trees after the 1986 growing season. The effects of the NHS on tree vigor could be the result of competition for water and/or nutrients, or a result of allelopathy. Although allelopathic effects of tall fescue have been noted on several species (Peters and Luu, 1985), we know of no such reports for peach. The growth response of peach to the NHS is probably a result of 


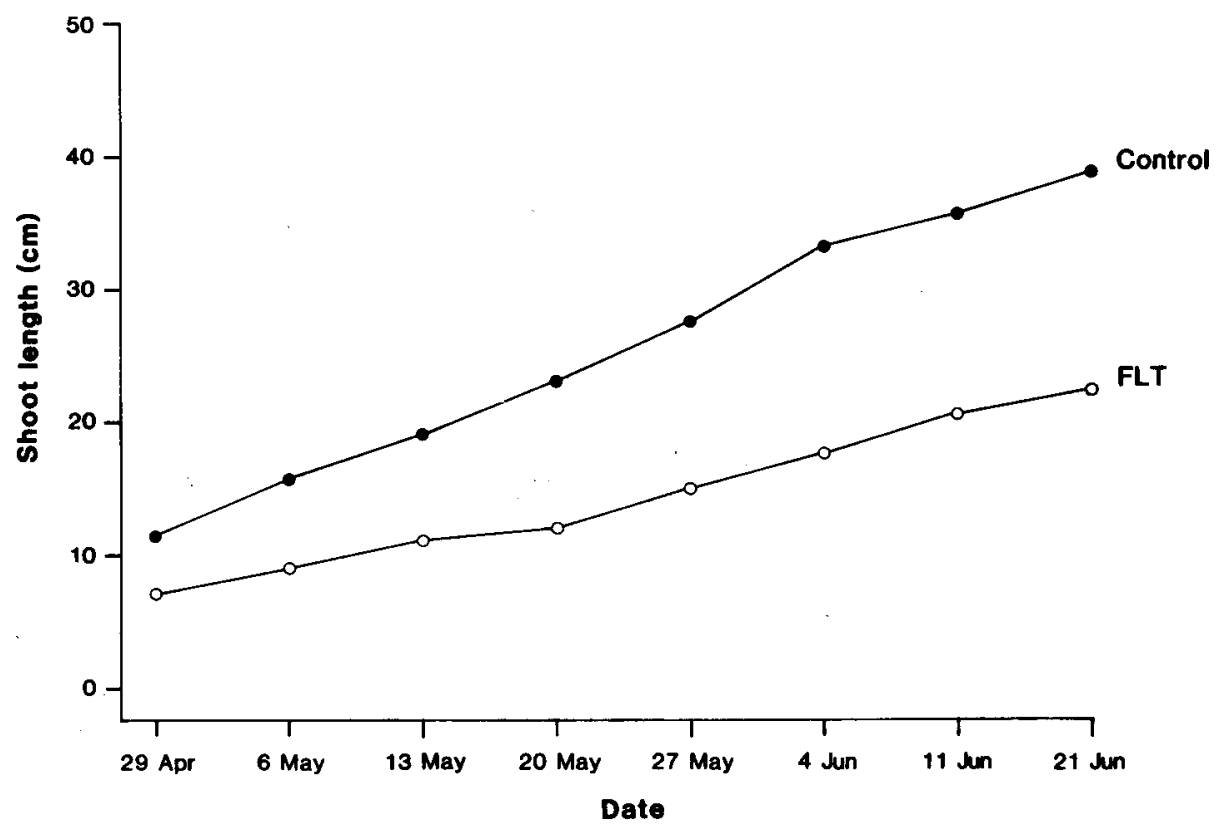

Fig. 2. The effect of planting treatment on shoot length $(\mathrm{cm})$ in 1986. Differences between trees in fiber-lined trenches (FLT) and control trees were significant at each date, $P<0.01$.

Table 2. Effect of planting treatments on shoot characteristics of 'Redhaven' peach trees in 1986.

\begin{tabular}{lccc}
\hline \hline Planting & $\begin{array}{c}\text { Flower bud } \\
\text { density } \\
\text { (flowers/cm } \\
\text { of shoot) }\end{array}$ & $\begin{array}{c}\text { Flowers } \\
\text { per } \\
\text { node }\end{array}$ & $\begin{array}{c}\text { Internode } \\
\text { length } \\
\text { (cm) }\end{array}$ \\
\hline Control & 0.17 & 0.30 & 1.9 \\
Auger & 0.14 & 0.25 & 1.8 \\
Raised bed & 0.19 & 0.34 & 1.9 \\
NHS $^{z}$ & 0.15 & 0.27 & 1.7 \\
FLT $^{y}$ & 0.26 & 0.45 & 1.8 \\
LSD $^{\text {(0.05) }}$ & 0.05 & 0.08 & 0.1 \\
\hline
\end{tabular}

${ }^{2}$ Narrow herbicide strip.

yFabric-lined trench.

competition for available nutrients during the spring, since tall fescue is relatively dormant during summer months in South Carolina. Additionally, no differences were noted between this treatment and the control for leaf water potentials measured during Summer 1986 (data not shown). Welker and Glenn (1985) reported closer proximity of 'Kentucky 31' tall fescue sod reduced leaf $\mathrm{N}$ and $\mathrm{Cu}$ concentrations and reduced growth of young peach trees. Similar effects on growth and leaf $\mathrm{N}$ and $\mathrm{Cu}$ concentrations were found for NHS trees.

The factor(s) controlling the initiation of flowering are not well-understood. Enhanced flower bud development of FLT trees may result from an alteration in the supply of growth substances from the roots to the shoots. However, as with many plants, excessive vigor of peach results in suppressed flower bud development. Conversely, the increased flowering of the FLT trees may have been a result of the level of vigor control achieved from fabric-lined trenches. Fruit were unusually small throughout South Carolina in 1986. Fruit from the experimental orchard were small, but only slightly smaller than fruit in nearby standard orchards. Fruit from the FLT trees had slightly smaller diameters than control fruit. This was probably due to the dif-

Table 3. Effect of planting treatments and irrigation levels on reproductive growth of 'Redhaven' peach trees in 1986.

\begin{tabular}{|c|c|c|c|c|c|c|c|c|c|}
\hline \multirow{3}{*}{$\begin{array}{l}\text { Planting } \\
\text { treatment }\end{array}$} & \multirow{3}{*}{$\begin{array}{l}\text { Irrigation } \\
\text { level }(\%)^{z}\end{array}$} & \multicolumn{4}{|c|}{ Fruit diam $(\mathrm{cm})$} & \multirow{3}{*}{$\begin{array}{l}\text { Mean } \\
\text { fruit/wt } \\
(\mathrm{g})\end{array}$} & \multirow{3}{*}{$\begin{array}{l}\text { No. } \\
\text { fruit/tree }\end{array}$} & \multirow{2}{*}{\multicolumn{2}{|c|}{ Fruit yield }} \\
\hline & & \multirow{2}{*}{$\begin{array}{c}\text { Stage } \\
1\end{array}$} & \multicolumn{3}{|c|}{ Harvest date } & & & & \\
\hline & & & 23 June & 26 June & 3 July & & & $(\mathrm{kg} /$ tree $)$ & $\left(\mathrm{kg} \cdot \mathrm{m}^{-2} \mathrm{TCA}\right)^{\mathrm{y}}$ \\
\hline Control & & 2.7 & 4.76 & 4.57 & 4.85 & 67.3 & 51.5 & 3.44 & 2000 \\
\hline Auger & & 2.7 & 4.80 & 4.61 & 5.02 & 70.5 & 36.1 & 2.50 & 1700 \\
\hline Raised bed & & 2.7 & 4.68 & 4.54 & 4.97 & 67.4 & 48.6 & 3.24 & 2000 \\
\hline NHS $^{x}$ & & 2.6 & 4.72 & 4.53 & 4.94 & 68.7 & 25.7 & 1.71 & 1300 \\
\hline FLT $^{w}$ & & 2.6 & 4.56 & 4.44 & 4.72 & 62.3 & 50.5 & 3.11 & 3300 \\
\hline \multirow[t]{3}{*}{$\operatorname{LSD}(0.05)$} & & NS & 0.16 & 0.11 & 0.27 & NS & 10.3 & 0.64 & 600 \\
\hline & 100 & 2.7 & 4.7 & 4.5 & 4.9 & 68.0 & 43.6 & 2.86 & 2100 \\
\hline & 12.5 & 2.5 & 4.7 & 4.5 & 4.9 & 66.6 & 41.3 & 2.74 & 2000 \\
\hline \multirow{2}{*}{$\begin{array}{l}\text { Significance betwéen } \\
\text { irrigation levels }\end{array}$} & & & & & & & & & \\
\hline & & $* *$ & NS & NS & NS & NS & NS & NS & NS \\
\hline
\end{tabular}

${ }^{z}$ Evaportranspiration replaced.

${ }^{y}$ Fruit weight per tree on a trunk cross-sectional basis.

${ }^{\times}$Narrow herbicide strip.

"Fabric-lined trench.

NS, ${ }^{*}$ Nonsignificant or significant at $P=0.01$, respectively, Fisher's F-test. 
Table 4. Effect of planting treatments and irrigation levels on elemental content of peach leaves in 1985 and 1986.

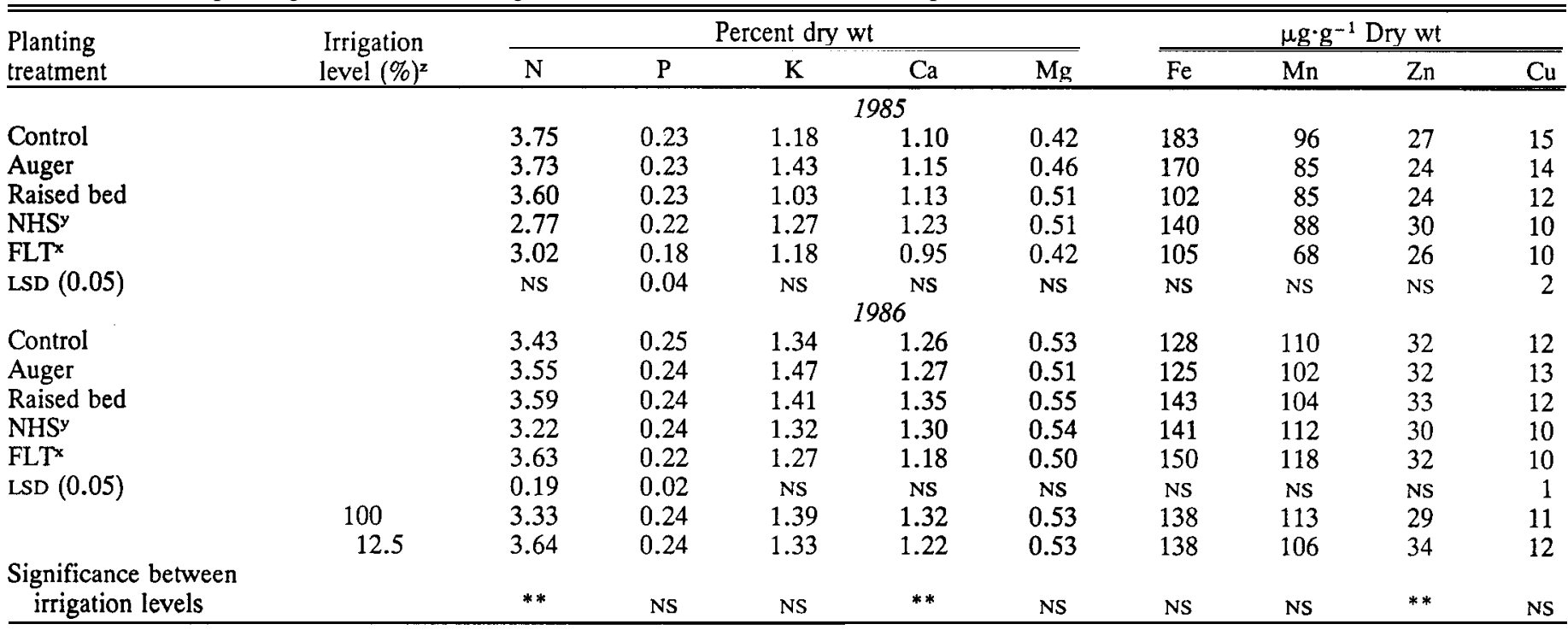

${ }^{2}$ Evapotranspiration replaced.

y Narrow herbicide strip.

xFabric-lined trench.

Ns," Nonsignificant or significant at $P=0.01$, respectively, Fisher's F-test.

ference in crop load between the treatments after thinning $(3.0$ fruit $/ \mathrm{cm}^{2}$ TCA for the control vs. 5.4 fruit $/ \mathrm{cm}^{2}$ TCA for FLT trees). Fruit were spaced $\approx 15 \mathrm{~cm}$ apart following thinning. However, natural fruit set was more evenly distributed along shoots in FLT trees than in controls, which resulted in greater crop loads in FLT trees after thinning. Optimum crop loads for trees with restricted root systems could be different from unrestricted trees. More research is needed to address this problem.

Lower foliar P concentrations observed in the FLT trees demonstrate the importance of proper fertilizer placement for trees with restricted root systems. Soil P was determined to be present in sufficient quantities based on soil testing, and no applications of $\mathrm{P}$ were made during the study. Without restriction, continual growth and exploitation of new soil by the root system allow plants to absorb water and mineral nutrients required for growth. The low level of foliar $\mathrm{N}$ observed for the NHS trees in both years was most likely due to the use of $\mathrm{N}$ by the encroaching fescue.

FLT trees grew at a rate similar to the controls until the second growing season. It appears that trees could be allowed to fill their allotted space in a high-density orchard quickly by the use of fabric-lined trenches of appropriate size. The proper trench size, or proper root volume, would no doubt depend on many variables, such as plant spacing, soil type, fertility regime, and method of irrigation.

Of the planting systems tested, fabric-lined trenches were most encouraging in suppressing canopy volume and increasing yield efficiency. Fabric-lined trenches may afford a practical approach to controlling tree size for tree fruits with no suitable dwarfing rootstock. Future research should be focused on identifying other methods of restricting root growth in the field and on determining appropriate root volume needed to achieve the desired suppression of vigor for the species under study.

\section{Literature Cited}

Bradford, K.J. and S.F. Yang. 1980. Xylem transport of 1-aminocyclopropane-1-carboxylic acid, an ethylene precursor, in water logged tomato plants. Plant Physiol. 65:322-326.

Bradford, K.J. and S.F. Yang. 1981. Physiological response of plants to waterlogging. HortScience 16:25-34.

Buttrose, M.S. and M.G. Mullins. 1968. Proportional reduction in shoot growth of grapevines with root systems maintained at constant relative volumes by repeated pruning. Austral. J. Biol. Sci. 21:10951101.

Chalmers, D. J., P.D. Mitchell, and L. van Heek. 1981. Control of peach tree growth and productivity by regulated water supply, tree density, and summer pruning. J. Amer. Soc. Hort. Sci. 106:307312.

Cockcroft, B. and J.C. Wallbrink. 1966. Soil properties and tree vigor in the Goulburn Valley. Austral. J. Expt. Agr. Anim. Hush. 6:204208.

Delwiche, M.F. and R.A. Baumgardner. 1983. Ground color measurements of peach. J. Amer. Soc. Hort. Sci. 108:1012-1016.

Havis, L. 1938. Peach tree root distribution. Ecology 19:454-462.

Kende, H. 1965. Kinetin-like factors in the roots of sunflowers. Proc. Natl. Acad. Sci. USA 53:1302-1307.

Mitchell, P.D. and D.J. Chalmers. 1983. The effect of reduced water supply on peach tree growth and yields. J. Amer. Soc. Hort. Sci. 107:853-856.

Oskamp, J. 1933. The rooting habit of deciduous fruits on different soils. Proc. Amer. Soc. Hort. Sci. 29:213-219.

Peters, E.V. and K.T. Luu. 1985. Allelopathy in tall fescue, p. 273283. In: A.C. Thompson (cd.). The chemistry of allelopathy, biochemical interactions among plants. Amer. Chem. Soc., Washington, D.C.

Phillips, I.D.J. and R.L. Jones. 1964. Gibberellin like activity in bleeding sap of root systems of Helianthus annus detected by a new dwarf pea epicotyl assay and other methods. Planta 63:269-78.

Richards, D. and R.N. Rowe. 1977. Effects of root restriction, root pruning and 6-benyzlaminopurine on the growth of peach seedlings. Ann Bet. 41:729-740. 
Richards, D. and R.N. Rowe. 1977. Root-shoot interactions in peach: the function of the root. Ann. Bet. 41:1211-1216.

Sitton, D., C. Itai, and K. Kende. 1967. Decreased cytokinin production in the roots as a factor in shoot senescence. Planta 73:296-300,

Vaadia, Y. and C. Itai. 1968. Inter-relationships of growth with reference to the distribution of growth substances, p. 65-69. In: W.J. Whittington (cd.). Root growth. Butterworths, London.
Waring, P.F. 1970. Growth and its coordination in trees, p. 1-21. In: L.C. Luckwill and C.U. Cuttings (eds.). Physiology of tree crops. Academic, London.

Welkner, W.V. and D.M. Glenn. 1985. The relationship of sod proximity to the growth and nutrient composition of newly planted peach trees. HortScience 20:417-418. 